\title{
THE FARMHOUSES OF THE ROMAN COUNTRYSIDE: CENSUS AND CATALOG. THE CASE OF THE ESTATE OF FARNESIANA
}

\author{
D. Calisi ${ }^{1, *}$, A. Zappa ${ }^{1}$ \\ ${ }^{1}$ Dept. of Architecture, ROMA TRE University, Rome, Italy - daniele.calisi@ uniroma3.it, and.zappa@stud.uniroma3.it
}

\section{Commission II, WG II/8}

KEY WORDS: Cultural heritage, Digital archive, Cataloguing, Virtual reconstruction, Digital Survey

\begin{abstract}
:
Rome is one of the cities with the largest green areas in the world, spread in villas and estates, within the municipal territory. But there is also a landscape triangle that radially branches out from the historic center, including a variety of unique situations (archaeological, historical - social, settlement, agriculture ...) in the world: the Caffarella and aqueducts Park. Inside, the Farnesiana estate, Capo di Bove, it's a witness of a widespread degradation process in the Roman countryside, which requires a gradual procedure of knowledge, cataloguing, restoration and re-functioning of the historical heritage. In this regard, the research is part of a larger study project of the Department of Architecture of Roma Tre, concerning farmhouses of the Roman countryside that deal with worrying degradation conditions and which require imminent intervention.
\end{abstract}

\section{INTRODUCTION}

Rome is an endless source of case studies belonging to a cultural heritage with a value probably unique in the world. The entire Old Town is UNESCO world heritage site, although it is an attractor for tourists but also researchers from all over the world, it partly tarnishes a much wider cultural heritage, outside the Aurelian walls, also of unparalleled historical, artistic and sociological value.

\section{THE GREEN SYSTEM IN ROME}

The Roman countryside has been, starting from the XII century, slowly divided into estates and villas. Specifically, is plenty of evidences of the past that describe the situation of Roman Agro, although starting from the XVI century. Before this date, the only information available can be deduced from notarial deeds which however do not provide reliable and unequivocal data, and especially do not recover the dimensional and / or formal aspects. The first general map of the Agro Romano was drawn up by Eufrosino della Volpaia; "Il paese di Roma e tutti $i$ luoghi particolari d'intorno Roma per XX miglia ", from 1547. About a century later it was promoted by Pope Alexander VII (1660) the realization of the Alexandrian Land Registry, which included 400 maps of the Roman countryside and its estates (Ashby, 1914).

In both cases, we are faced with the typology of representation typical of the epoch, in a phase of transition between the pseudo-perspective and the iconographic representation. While the first type of typology is easy to understand from a threedimensional point of view even through the architectural emergencies of the Roman countryside, on the other hand it does not provide precise dimensional information.

Definitely, an attempt in this direction is made by the Catasto Alessandrino, although, depending on the surveyors who compiled maps, the information we actually find, cannot be really easily compared: sometimes with details and quality, other times poor even of basic notions. Besides the metric scales and orientation are not always the same, creating more confusion (Figure 1).
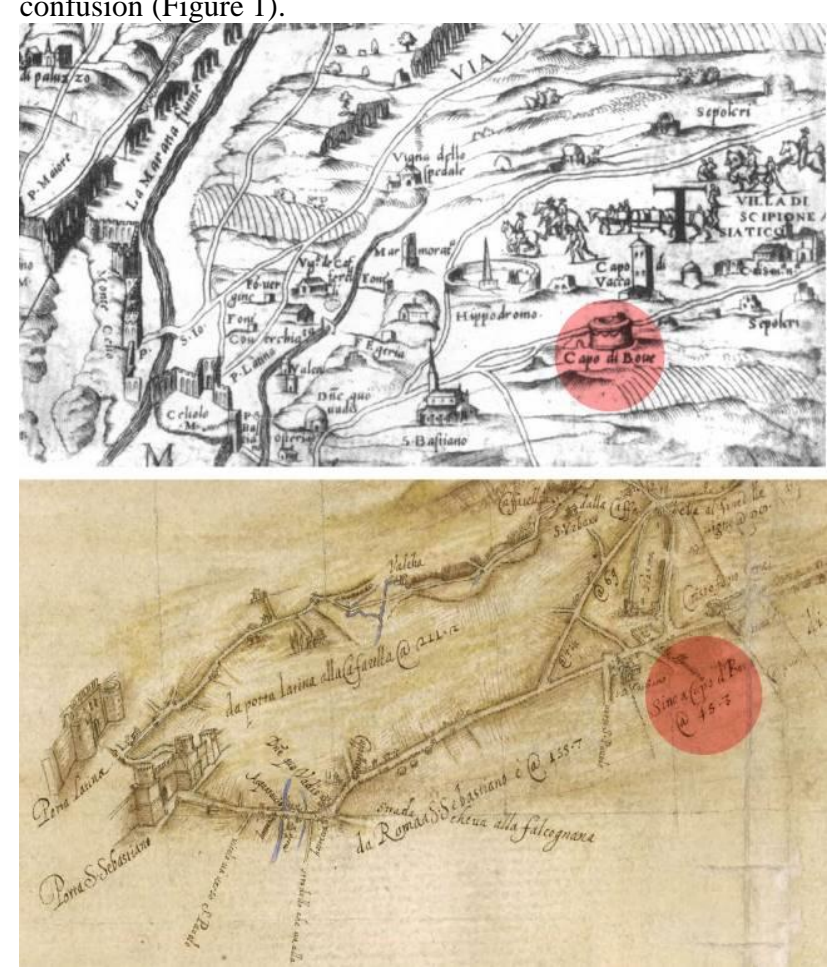

Figure 1. The first representations of the Roman Agro, above Eufrosino della Volpaia (1547), Catasto Alessandrino (1660). Identification of locality Capo di Bove.

The paper by Giovanni Battista Cingolani della Pergola is very important "Topografia geometrica dell'agro romano overo la misura pianta e quantia di tutte le tenute, e casali della campagna di Roma con le città terre, e castelli confinanti ad esse tenute le strade fiumi fossi acquedotti, et altre cose principali, e memorabili si antiche come moderne" of 1692,

\footnotetext{
* Corresponding author Daniele Calisi
} 
which, although with a worse graphic quality, gives more detailed information even in terms of visual emergencies. In particular, the estate of Capo di Bove, once called the five towers, is easily recognizable, both from the neighboring emergencies of the mausoleum of Cecilia Metella or from the Annunziatella estate, and from the presence of the five towers, the last of which, the "Zampa di Bove" tower collapsed during a storm in 1985 (Figure 2).

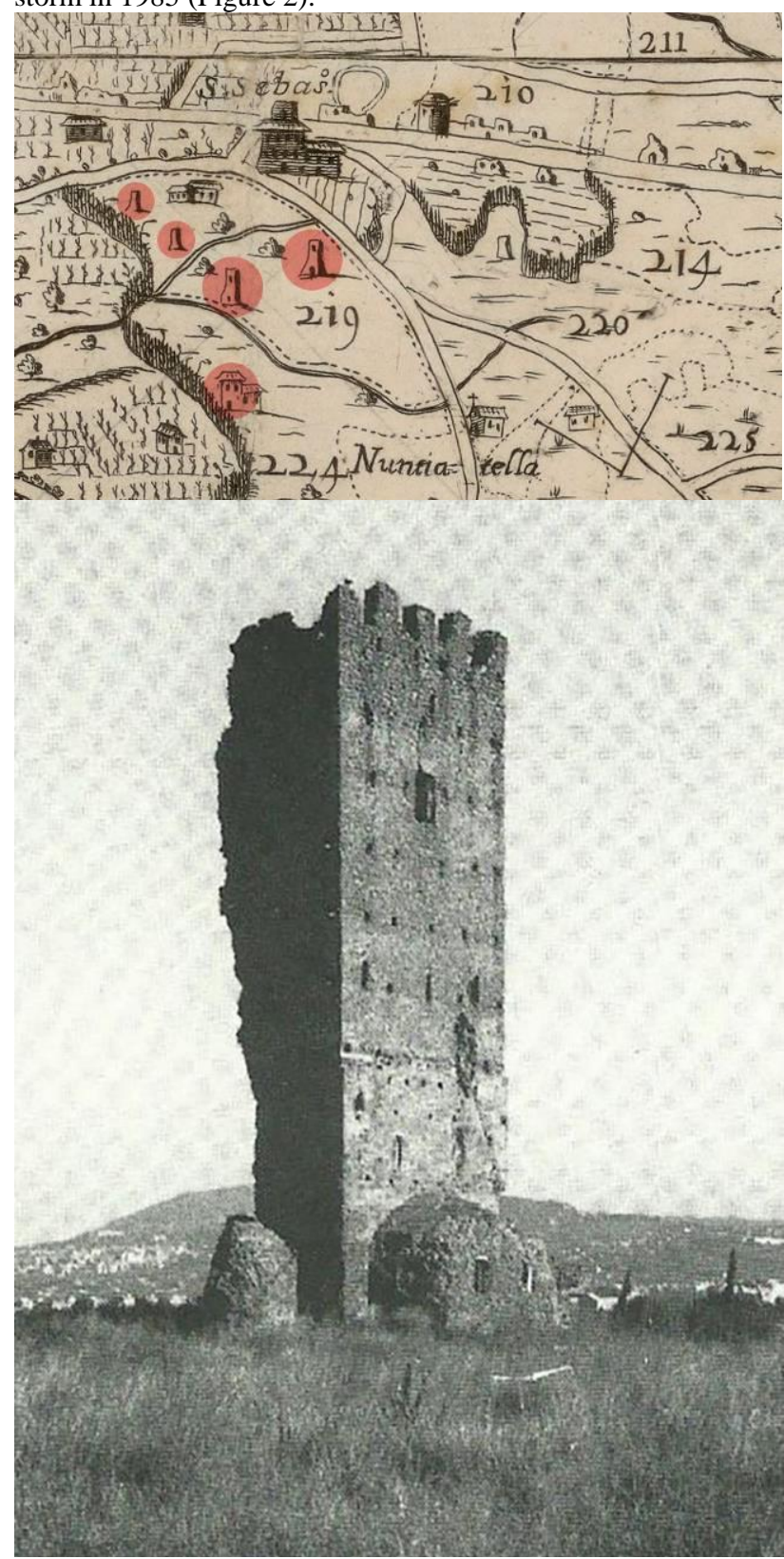

Figure 2. Planimetry of Giovanni Battista Cingolani della Pergola (1692) with identification of the Cinque Torri estate, the old name of Capo di Bove and of the respective defensive towers inside it. Below, Zampa di Bove, the last of the five towers, collapsed in 1985, due to the lack of maintenance interventions adequate for stability.

In 1913, furthermore, Pompeo Spinetti published his "Carta dell'Agro", on a scale of 1: 75000, with indications on the estates, the respective cadastral boundaries, the ownership and the extension.

The French historian Jean Coste, one of the greatest scholars of the Roman countryside, counts more than 400 houses in the territory during the Renaissance. However, over the centuries the situation has changed considerably, the condition of the structures has gradually and inexorably deteriorated, so that today only a hundred of the original hamlets remain and are still today in conditions of extreme decay. One of the main reasons that led to the abandonment of these structures was the gradual urbanization of the Roman countryside, especially in the last century, with the emergence of new and increasingly peripheral neighborhoods. It is interesting to note that this phenomenon is, actually, contrary to that which occurred in the rural countryside of central Italy, where another secular management system was set up: sharecropping. Widespread since the 12th century, it suffered a fate similar to the phenomenon of incasalamento (incasalisation), but with opposite causes: the decline in this case was due to the growth of cities and the migration towards them in search of more promising jobs and living conditions.

The phenomenon of incasalization, so defined by the Coste, had its first development between the XIII and XIV centuries. with the construction of the new farmhouses. However, documentary sources relating to this phase are rare and inaccurate. The defensive apparatus connected to the housing structures and functional to the agricultural culture, let think that the farmhouses were permanently inhabited by families. It is probable, as it also happens for the tenant farmers, that in periods of greater work in the fields, the families were joined by seasonal workers (Coste, 1969).

In the second phase, between the fourteenth and fifteenth centuries, there was a first abandonment of the farmhouses, due to a demographic collapse and to the increase in pastoralism, as well as to socio-political problems that made safety in the Roman countryside very unstable. The construction of new farmhouses is rather rare and is often the result of land consolidation.

The socio-political situation affecting these structures is rather complex. At first the farmhouses were in the hands of the ecclesiastical bodies or the baronial nobility that they managed, under contract, to people and families who cultivated the land. These subjects are identified in the acts as bobacterii (agricultural merchants), mercatores or compsores, and over time they take on more and more economic power to be, in the XIV century. assimilated to the barons themselves (Carocci, 2004).

The farmhouses are built in a strategic way, choosing useful positions for the development of the companies. They are all close to the main communication routes and also to waterways, obviously for the supply of land for the cultivation of the land and for the watering of the cattle.

On the other hand, these features are also common to the productive villas built at the Roman time, and the countryside is rich in archaeological remains in this sense (Figure 3). It often happens, in fact, that the houses are built on Roman preexistences, in some cases adopting the original functions, as for the cisterns (Ashby, 1970). In other cases, the ruins become foundations for new masons, while the old hypogeal rooms turned into warehouses or ice-houses (as in the Farnese estate). As often happened in Rome, the Roman remains become open quarries for the recovery of materials to be used in the construction of the houses, and it is common to find, set in the new walls, pieces of travertine, marble and decorations used to interpose the joints of bricks, or for architraves and door or window frames.

Another characteristic element is certainly the presence of towers, often indicated also in the lease contracts, which were used primarily as a defensive and sighting element, but at the same time to prove the power of the noble family that owned the fund, as happened in the city where the influence family was 
shown itself through towers higher than the others. The Capo di Bove estate itself, the subject of the research, had previously taken the toponym of the Cinque Torri, referring to the presence of watch towers particularly useful in this area, an elevated plateau from which it was easier to spot brigand raids or troops. Nothing remains of the five towers today. The last one to collapse, due to the lack of maintenance of the rural structures, was that of Zampa di Bove in 1985. The remains can be seen from via Muraccio dell'Ospedaletto, a road that branches off from the Appia Antica up to via Caetana, between Cecilia Metella and Tor Carbone, and flanks the Air Force depot. They are located in a meadow with other ruins (those of the other 4 towers, which were part of a defensive signaling and control system at the service of the castle that the Caetani built on the Appia Antica, incorporating the mausoleum of Cecilia Metella).

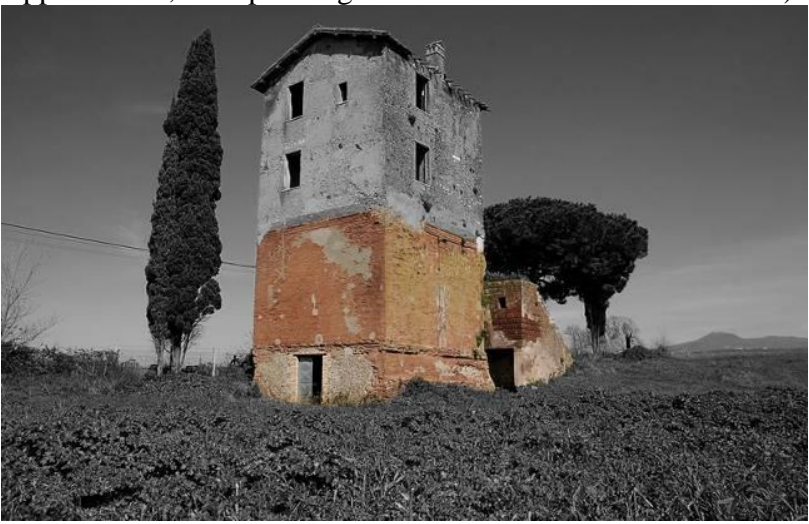

Figure 3. An example of reuse of Roman pre-existing buildings: the tower of Santa Maria in Fornarola, built on the remains of a domuscultae (in color in the image).

Beyond the house and the tower, there were other functional structures for agricultural activities: the mandre, places where to keep pets; the pute $i$ where the cereals, cellars and cisterns often existed were kept; irrigation channels; Grypte and arnarie, that is, caves also deriving from older and often hypogeum structures. Most of the new walls are of the sack type, consisting of an internal cement core with inert materials of different sizes and of an irregular shape enclosed by two external walls, generally in bricks or tufa blocks of more geometric shapes and rather row plants. regular with alternate joints. In some cases, rarer and later, the masonry wall has a lower geometric regularity, consisting of irregular tufa blocks called "tufelli" of about $15 \mathrm{~cm}$.

Some of these features are also found in the architectural nucleus under study on the estate of the Farnesiana or Capo di Bove.

\section{CAPO DI BOVE ESTATE}

In particular, the Via Appia Antica, the Roman consular road, radiates beyond the Porta San Sebastiano and after about a mile the Via Ardeatina also engages, giving rise to a segment of the city that has remained almost intact.

In addition to the countless historical and archaeological emergencies, one of the factors that characterizes the area, like other Roman ones that were prevalently agricultural in history, are the estates and farmhouses, often built in the neighborhood or above pre-existing ruins of the classical age now mostly disused (Esposito, 2005).

The theme of the research is part of a much broader picture of the farmhouses of the Roman countryside, which are gradually being cataloged, surveyed and analyzed, by virtue of a knowledge not only of the current state, but also forecasts of new and future uses compatible with the area of interest (Geremia, Zampilli, 2013).

The architecture is located between the districts of Ardeatino and Appio-Pignatelli, the area best known as the "Farnesiana", a territory that suffered the same fate of all the Agro Romano, it became an area of food supply storage throughout the city. From this, it is assumed the agricultural setting of the rural building of the area.

The Farnesiana rests in part on a layer of black hard stone called leucitite, in Rome is called inappropriately flint. Leucitite is the stone used for the "sampietrini" and the basolates of the ancient consular roads, and it is a lava rock.

The formation date back to the last active phase of the Volcano Laziale, about 190,000 years ago, and it went to lean above the thick layer of pyroclasts (tuffs and pozzolans), forming a height survey of over 10 meters on the surrounding countryside.

This geological structure has been called "Capo di Bove", taking its name from the medieval name of the tomb of Cecilia Metella (Figure 4).

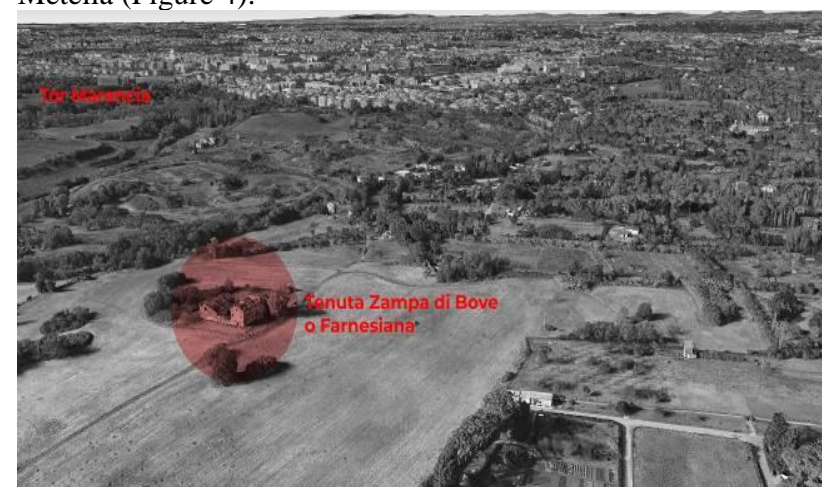

Figure 4. View of the Capo di Bove estate, in the direction of the historic center of Rome. On the left is the Tor Marancia estate, also of considerable importance.

The estate consists of about 70 hectares of land. Despite such a limited extension it is possible to find a great diversity of environmental and archaeological realities. The small but important Farnese grove of mixed wood, unique in its territory in the Appia Park, includes holm oak, Roverella and some Sughere trees and, in the undergrowth, the Hawthorn and the Marruca.

The Casale belonged to the Farnese family, hence the name of the Farnesiana, and was built at the end of '700, then sold to the Torlonia family around 1810 . The house took the name of Vigne Viola, for the presence of vineyards then disappeared when the Torlonia concentrated their financial resources on the possessions in the center of Rome. Moreover, with the unity of Italy the cities had a strong demographic raise with consequent increase in the need for bread: this led to the replacement of the expensive cultivation of vines with that of wheat.

\section{TYPOLOGICAL ANALYSIS: VIGNE VIOLA FARMHOUSE}

It is necessary to make a distinction between the farmhouses present in the Lazio region and specifically those that can be found in the Roman countryside. The rural farmhouses of the Roman countryside are buildings which have characteristics that are sometimes very different from eachother. Factor due in first analysis to the different formation period and to the extension of the portion of territory that has been chosen to analyze, and, no less important, the intended use for which these buildings were used and their position relative to territory of the city. 
The typology of the Roman farmhouse is that of the rustic with almost always square or rectangular plan of simple geometry, with the habitation of the farmers in general on the first floor and with the addition of an elongated body of service (storage stables). Below the house, on the ground floor, there is the "vaccareccia", the dining room (storage of wine vats) and the cart shed, while on the upper floors, there are often cereals and food pantries deposits, especially for houses with agricultural functions (Mazza, 1991).

The case study is placed in a typology of late eighteenth-century country house, where generally the buildings were distinguished in two uses: the first one that saw the house of the farmer who had the task of making productive the landowner's ground; the second one as a hunting lodge, since, often, the ancient noble families were owners of fenced land (ancient barchi) used exclusively for hunting, where they used to stay for longer or shorter periods. So farmhouses had to present some suitable features in order to satisfy the needs of the family and those of public relation as well, due to the political and social nature in which this activity could consist.

This is precisely the case of the Vigne Viola farmhose, built at the end of the 18th century, probably by of the Farnese family used as a hunting reserve, also for the peculiar characteristics that the territory presented, like the presence of a very thick tree cover of which today only the "Farnese grove" remains near the building, later sold, together as well as the estate, to the Torlonia family around 1810 (Figure 5).
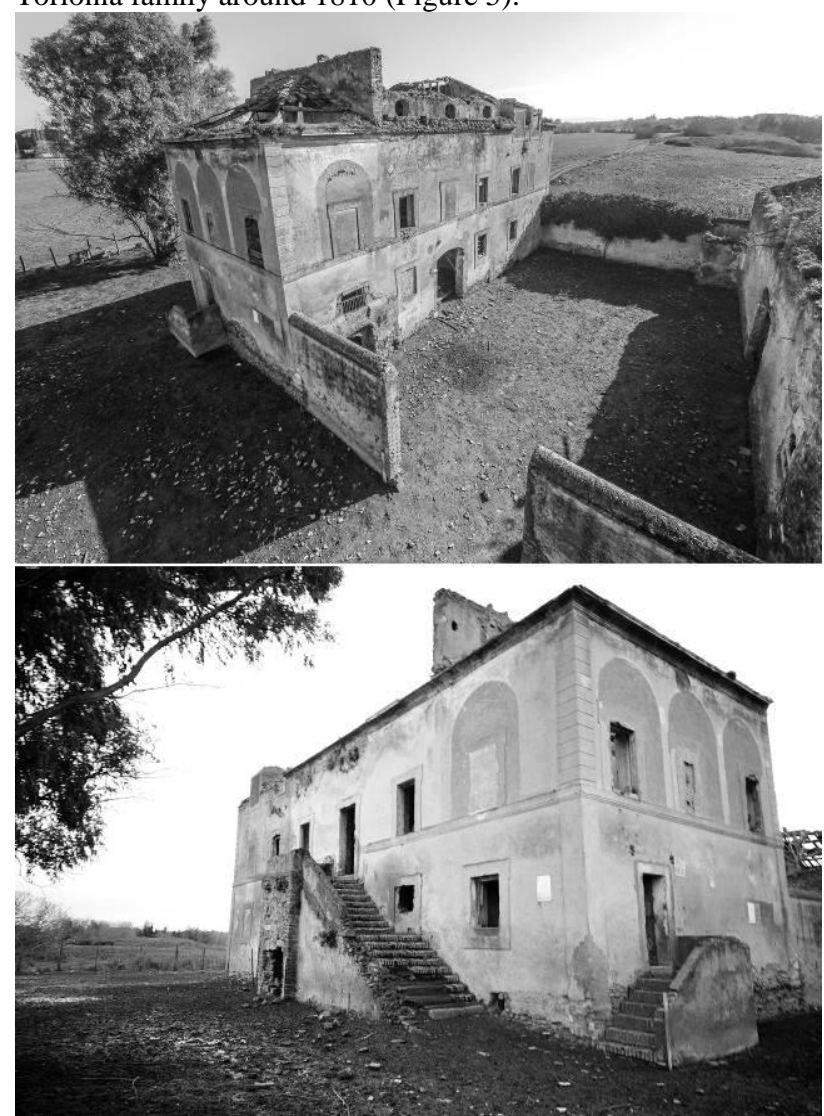

Figure 5. Two views of the Vigne Viola farmhouse.

The land it's built on has a history which has its roots in Roman times, there is an evidence of pre-existing Roman buildings that indicate that the territory of the Farnesiana suffered the same fate just like all of the Agro Romano, becoming a supply area for supplies food for the whole city.

In particular, there was the "fundus rosarius", which corresponded to the southern part of the Farnesiana, dedicated exclusively to the cultivation of roses. With the fall of the empire and the depopulation of the countryside around Rome, the Farnesiana was also abandoned. In the Middle Ages the estate was part of a larger system that was then fragmented and sold in the current possessions, the property passed to the Farnese family, hence the name of the estate. In this phase several farmhouses were built in the area, including the one being studied and the Vignacce one, in the southern part of the estate, used instead as an agricultural residence.

The Vigne Viola farmhouse is made up of two harmonious buildings, one used as stables and service rooms and one as a main residence, with an internal courtyard and a large external square with the remains of a large octagonal fountain. The main part consists of a building, hypothetically, originally with two floors (now at 3 ) with a small arched loggia (now walled) which has elliptical openings on the long side that recall the stylistic motifs of the suburban villas of the seventeenth century (Villa York, to quote the most famous and complete).

The stable and the barn can be reached on the upper floor with an external staircase, typical of central-southern farmhouses where little or nothing snows. Outside, in line with the entrance to the inner courtyard, is the cistern for collecting water, with an octagonal plan, decorated with decorations, connected to an irregularly-shaped fountain with curved lines that recall the Baroque.

In the east facade of the building there is an opening that gives access to a completely underground room which was originally accessed via a staircase, now completely covered by debris caused by a probable collapse of the plastered surface of the vault above. This environment is assumed to be a pre-existence on which the farmhouse was built, specifically a Grypta, used as an icebox, whose function derives from the oldest or partly underground structure.

To reinforce this hypothesis there are stone elements of uncertain provenance visible on the façade, and now sealed, but certainly of a previous era, which could have been used as vents, a recurring element of the Grypte.

The current appearance of the building is partially modified compared to what originally was supposed to be, both in its external composition, such as the walled loggia clearly visible in its formal components (Fig. 9) and in the internal distribution, where numerous accesses have been closed and others have been opened in order to realize new rooms that we could define "apartments", as well as the addition of a half floor in the attic for the same reason.

The main building has many gaps in the plaster, probably due to the erosive action of weathering that caused the detachment, which allow to inspect the superficial portion of the perimeter walls. It is therefore possible to observe a recurrent basement on the east side and in hypothesis on the west and south side, formed by a mixed wall of black basalt of variable size and light yellow brick of length between 11 and $30 \mathrm{~cm}$, width between 15 and $18 \mathrm{~cm}$, and thickness between 2.5 and $5 \mathrm{~cm}$; a large part of the masonry is made of rough-hewn stone to facilitate the placement and with bricks used to regularize the laying surface. This is held together by a tenacious pinkish-colored mortar with small and medium-sized aggregates, such as red pozzolana.

The use of basalt is peculiar to the Farnesiana estate, in fact, unlike most of the neighboring estates such as Tor Marancia, which is essentially made up of tuffs and pozzolan, the Farnesiana rests on a layer of black and very hard stone, as mentioned previously "leucitite", available following the formation of the structure of the "Campo di Bove flow".

The base section of the north side, on the other hand, has a different conformation in that it is generally composed of what is assumed to be Tufo di Gallese, Tufo di Sacrofano (for the 
recurrent use that has been made of it in other constructions and for the proximity of the extraction points) and brickwork. The mortar in this case of gray color also has small aggregates such as pumice in the red pozzolana.

The wall layer resting on the basement can be seen in the south elevation where there is a collapse that reveals an opus incertum type of masonry composed of a conglomerate of mortar and stones, mainly basalt and light-yellow sandstone; hypothetical layer also on the remaining sides of the building (Figure 6).

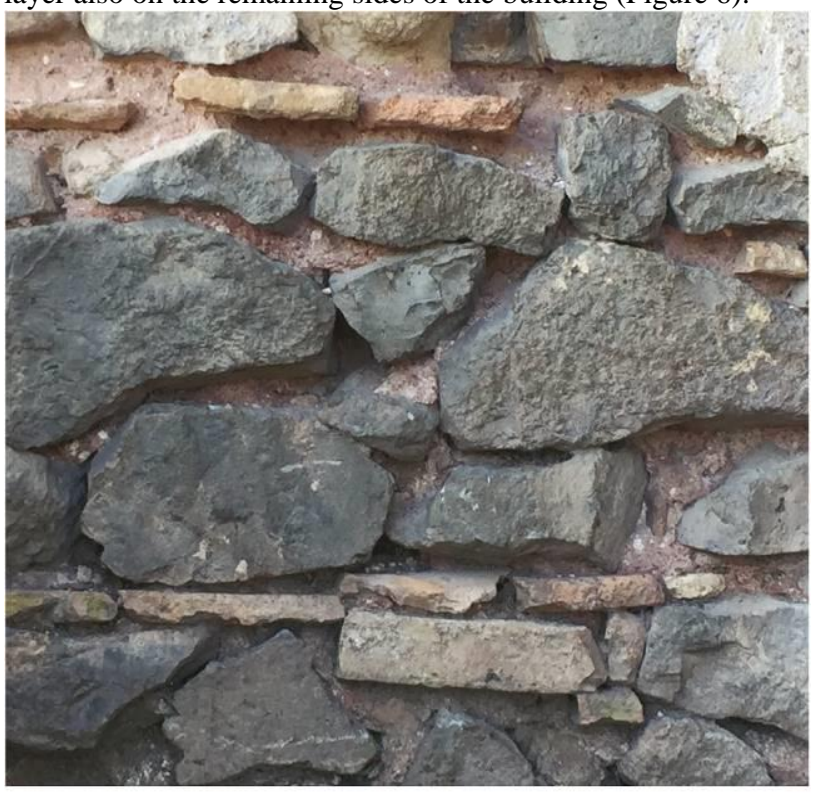

\section{WALL BASEMENT}

\section{COMPOSITION:}

Basalt , Full Bricks

COLOURS and DIMENSION:

Black basalt variable dimesion, Straw yellow Bricks length $11 / 30 \mathrm{~cm}$, width $15 / 18 \mathrm{~cm}$, thickness $2.5 / 5$ $\mathrm{cm}$

\section{MORTAR DESCRIPTION:}

The mortar shows itself tenacious, with a pinkish color, with small and medium-sized aggregates such as red pozzolana.

\section{DESCRIPTION:}

Mixed masonry composed of basalt and brick. The stone material is the most present, worked by roughening it. The bricks have the function of regularizing the laying surface.

\section{STATE OF PRESERVATION:}

Poor. As the original plaster layer has gaps that have accelerated the alteration process of the wall face

Figure 6. Example of knowledge, survey and analysis of one of the present wall hangings of the Casale delle Vigne Viola.

In the inner part of the building there are few examples of what the original floors should have been, as the numerous stratifications that followed over the years make it difficult to analyze the structure of the floors. As well as the rehabilitation of the building for civilian use, which, could have been made not later than the first half of the 20th century, considering the materials used, as a consequence of the housing emergency that had affected the whole Italian territory in those years of crisis. The only ones that have remained partially intact are those present between the ground floor and the first floor of the building.

Judging by the structure, the type of floor appears to be rather simple, realized with the recurrent method of the farmhouses of the time: central load-bearing beam, joists, rulers, wooden planks, clay filling, bedding and bricks in full brick; which in present times presents with the addition of a second bedding layer and the laying of ceramic tiles typical of the 1950s.

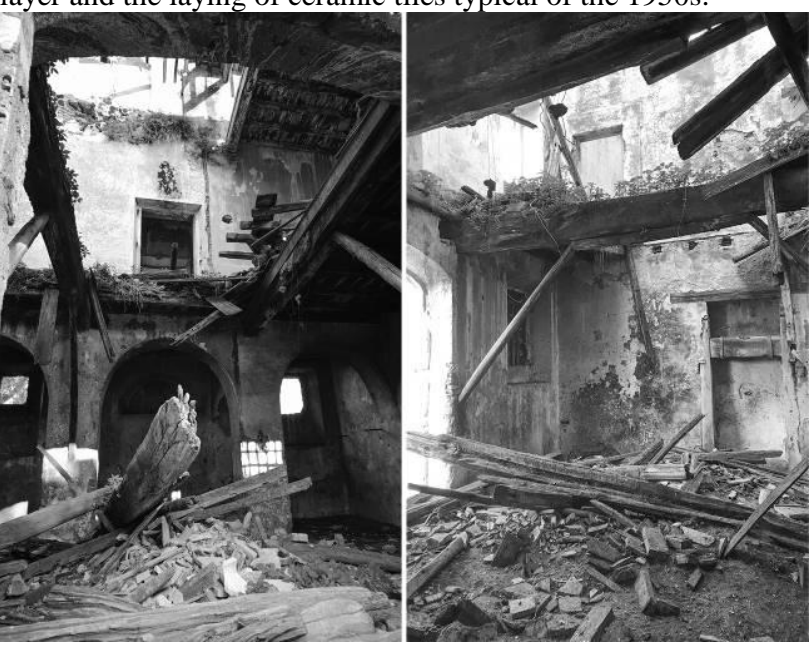

Figure 7. Internal collapses denounce the state of abandonment and the impossibility of detecting some Casale's areas.

The numerous collapses make it difficult to read the parts of the floor that still have a pavement (Figure 7). The visible parts described above for the floors which were partially walkable do not have a significant historical interest as they have recently been replaced. The only traces of original flooring are those found on the landing of the first-floor landing point of the profferlo and is presented in a discreet state of preservation with perimeter bands and internal herringbone mirroring typical of the farmhouses of the '700. The wooden roofs have suffered a greater degradation due to the atmospheric agents which were followed by collapses, even for the surely reconstructed parts. At this time the house has small portions of the roof still intact, but visibly unsafe, the main beams are in a state of irreversible decay. Most of the shingles used for the covering, seem to be of more recent invoice but in any case, also in a state of advanced degradation. Observing what remains visible through a photographic analysis with drone, the covering is assumed to have a double pitch starting from the south side for the first 3/4 of the building, up to the masonry where a second 3-pitch roof was supported, above the environment of the loggia, today completely collapsed.

\section{SURVEY CAMPAIGN}

The conditions in which the farmhouse is located today required an accurate survey campaign, first direct, through the tracing of an external polygonal, and subsequently instrumental for the methodical and analytical mapping of the materials of both surface and structural degradation (Cundari, 2015).

Survey is an investigative tool, analysis and knowledge of the architectural artefact. Its purpose is to return the image of the work, represented in different ways depending on the ultimate 
purpose. The architectural survey is not only a tool for measuring a building or an urban context, with its graphic representation, but a very complex operation that makes different disciplines interact, and that uses adequate and multiple tools and means (Feiffer, 2014).

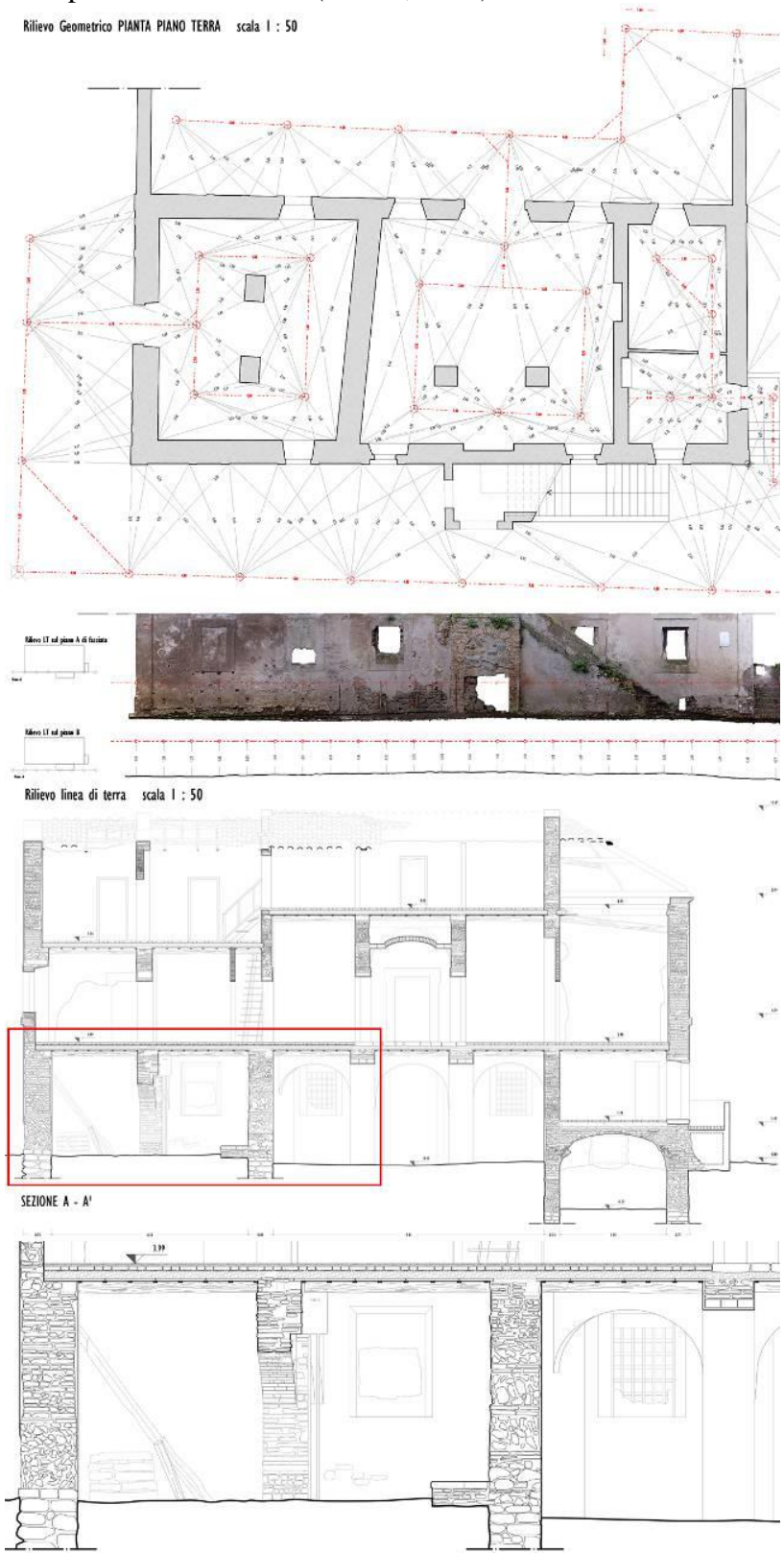

Figure 8. Direct survey with fixed external polygon. Section with identification of the wall types and detail of the former sheepfold on the ground floor with external access.

The peculiarities of each building are individual, and consequently the method to be applied is always different. Depending on the multiple historical periods we find ourselves having to deal with the study of construction techniques, materials and methodologies that are completely different. The survey allows to identify, analyze, file the origin of a building and the events related to it and suffered in the course of history (Almagro, 1999). It also allows us to analyze the different construction components within it and understand their evolution (Figure 8). Furthermore, cataloging the transformations undergone, identifying the characteristic elements and the additions and consequently also understanding the original structural morphology. Finally, based on the transformations undergone, it is possible to detect structural lesions. This complexity highlights a process that in itself hides both an objective component, which leads to wanting to know and show a given building in its current forms, and a subjective component, which obviously depends on what one wants to represent of that given building at the expense of what, instead, leave out (Figure 9).
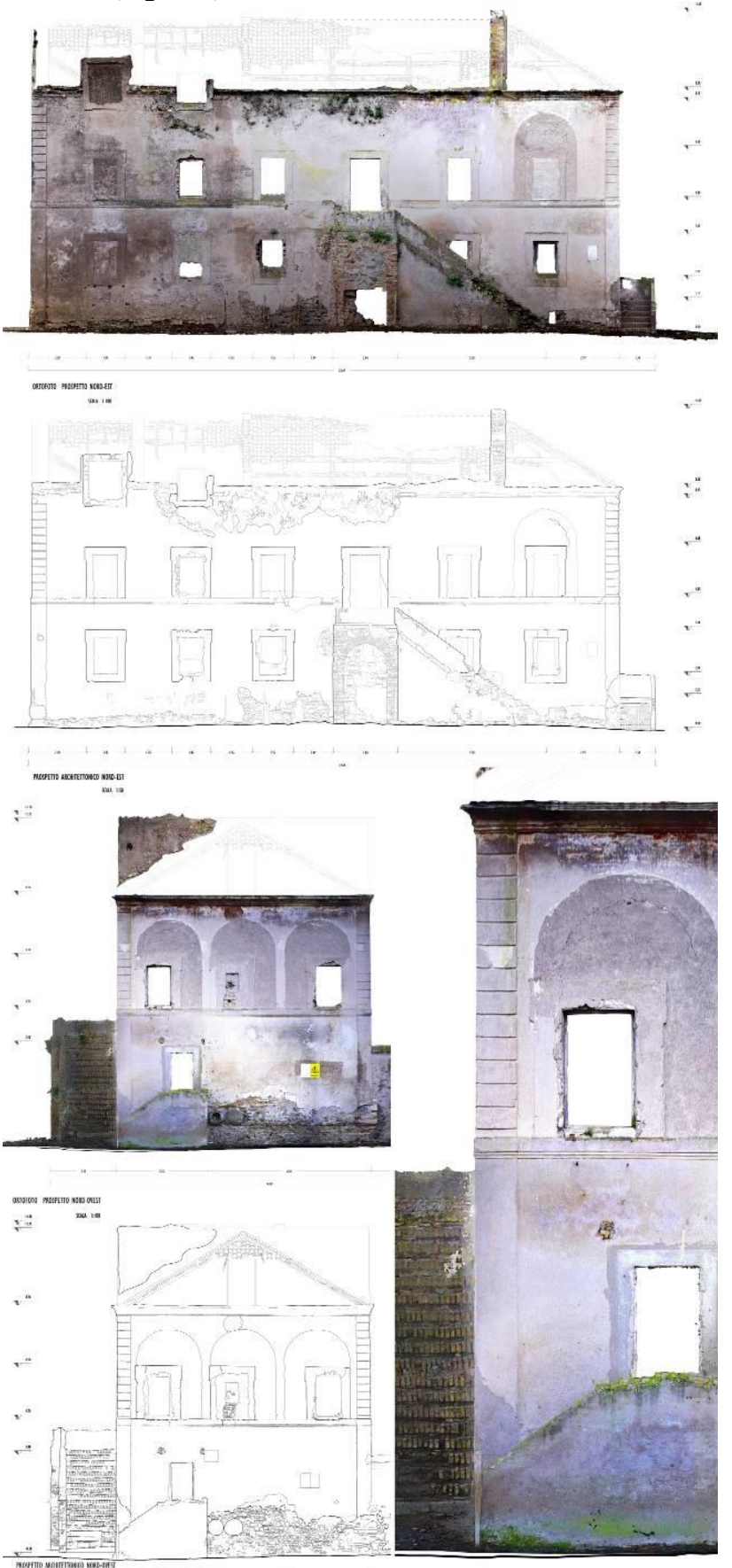

Figure 9. Survey of the elevations and identification of deterioration, superfetations and wall lesions. Orthophotopians made from the three-dimensional photo-model allow easy mapping of materials and deterioration. Below, the loggia on the first floor is clearly visible, whose walls have been walled up in recent times.

The discretization made by the detector depends on different factors, first of all the ultimate purpose of the Survey. It is 
necessary to know if the investigative act is functional to a relief for the restoration, for the historical-critical reading, for the archeology, or even for the estimate..

The discretization is not just about deciding which characteristic points to detect, but also about what actually needs to be detected. The complexity of an organism requires a complexity of drawings of equal size and in the appropriate scales of representation. The architect's geometric, spatial and proportional knowledge of an architectural work is an essential condition, even before the need for any bibliographic or historical-archival research.

In recent years, however, an indispensable instrument for the meticulous knowledge of a building has proved to be instrumental relief through the use of photographic or laser scanner techniques.

The possibility of accessing a three-dimensional model with high quality mesh detail and texture map, is in fact a considerable advantage for the analysis and later study of the building.

Particularly due to the material and degradation, new technologies have replaced the human eye, obsolete photographs or photogrammetry. Previously the knowledge of the material deck took place first of all through schemes and eidotypes taken from reality, which already implemented the process of discretization of the detector. Also, the photographs had their documentary function, and in some cases basic for the imprints.

However, the aberrations determined, first of all, by the position of the point of view, by the shortcuts, and secondly also by the optical aberrations, did not guarantee a perfect adherence of the preliminary analyzes with the scale and orthogonal projections. To this end, photogrammetry has allowed the perfect overlap between the photographic and orthogonal projections to be superimposed, however following work hours and with many difficulties.

SFM (Structure For Motion) software allows a much more dynamic and faster workflow, managing to put hundreds of high-resolution photographs into a system that allow the creation of textures for the proper mapping of the entire digitally recreated 3D model (De Luca, 2011).

The advantages are many. First of all, by working on $3 \mathrm{D}$ georeferencing, it is possible to have the digitized architecture perfectly scaled, with the possibility of being able to recover measures that are not accessible in the direct survey, or possibly verify the accuracy in case of dimensional inconsistencies.

The 3D georeferenced model, according to the parameters of wgs $84 / \mathrm{utm}$ zone $33 \mathrm{n}$, can be superimposed on the regional technical map in scale 1: 5000 downloaded in open data from the site of the region (Figure 10).

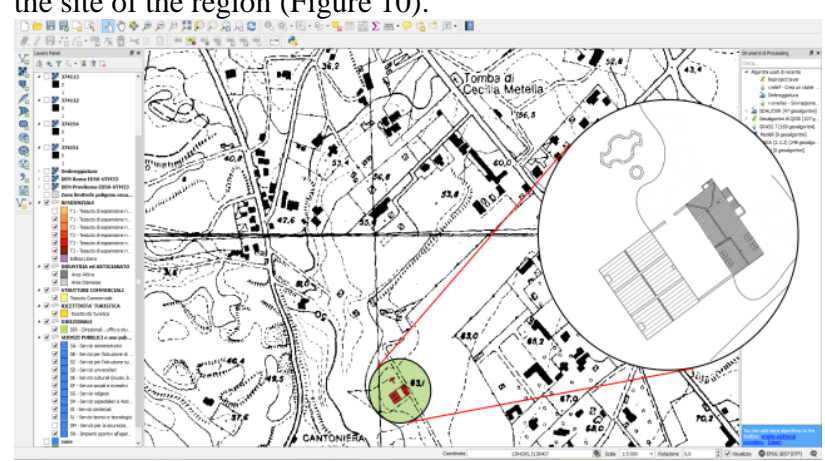

Figure 10. Georeferencing of the 3D model and the CAD file, through Qgis, on the regional technical map in scale 1: 5000.

The CAD can have a detail defined by the user.

It is therefore possible to create polygons (shapes) that highlight the built volumes, or geo-reference the Cad that derives from the surveys (direct and instrumental), as an additional level to the Qgis file with reference parameters that can provide indications on the state of conservation of the building. It is also possible to geo-reference the detail survey on the cartographic basis, in the scale required by the user.

It is possible to choose characteristic points on the photographs and the software will provide recognition and position the markers in the 3D model. They have the task of determining projection planes, generally coinciding with the masonry planes. This allows the easy export of orthophotopians: elevations in orthogonal projections, without shortcuts and improbable projections typical of the single photogram photographic return. Nowadays, orthophotos are indispensable for any relief aimed at restoration, because they guarantee a precise view of the material surfaces and their state of degradation. The perimeter and cataloging operation of similar areas can be done directly on orthophotos, also through CAD tools (Parrinello, 2013).

Thanks to the material reliefs obtained in this way it is easy to carry out a detailed mapping of the surface materials. The preliminary analysis coincides with the results underlying the instrumental survey, being able to easily perimeter materially similar areas, recognizing plasters, masonry in solid, mixed or filling bricks, stone apparatuses, wooden frameworks, as well as the decorative apparatus, divided into stuccos, frescoes or valuable flooring. This process is essential for the success of a restoration project, linking the full knowledge of the architectural artefact in all its material components, to the process of recognizing the degradations to which these materials have been subjected over time. This allows the restorer to make all the necessary and indispensable choices to ensure the recovery of the architectural work and return it to the restored art society.

The use of orthophotos in the field of restoration has an undoubted usefulness, however we must also remember that decisions on representation strongly influence the quality not only of the drawings, but also their easy communication to the client, to the firm, to the superintendencies.

The orthophoto can be integrated to the architectural survey, as a more complete tool of aid. If in fact the discretizations necessarily carried out by the designer for example, the visualization of the superficial wall apparatus on the elevations introduces a representative simplification, the orthophotos are not subjected to this process: the orthophoto returns exactly all that has been object of the photographic campaign and creating the three-dimensional model.

The software does not make a choice of information to show, however, again at the request of man, it can lower the resolution of the image with consequent loss of detail and even data. The simplification process, therefore, is one of loss of data quality and not of quantity: the information is the same but with ever worse quality. It is therefore appropriate to maintain the quality of high orthophotos, and to implement the critical selection process that leads, for example, to the drawings of material analysis.

In certain contexts, it is particularly recommended to use a drone that allows to photograph the architecture in its entirety, in virtue of the numerous instabilities found in pitched roofs, so that it may be possible to reconstruct the $3 \mathrm{D}$ model.

The photographic campaign has allowed the reconstruction of a virtual model and the faithful restitution of the orthophotopians of the four elevations and of the roof, with greater ease in the identification of the missing areas, absent or detached or of cracks, collapses and erosion. 

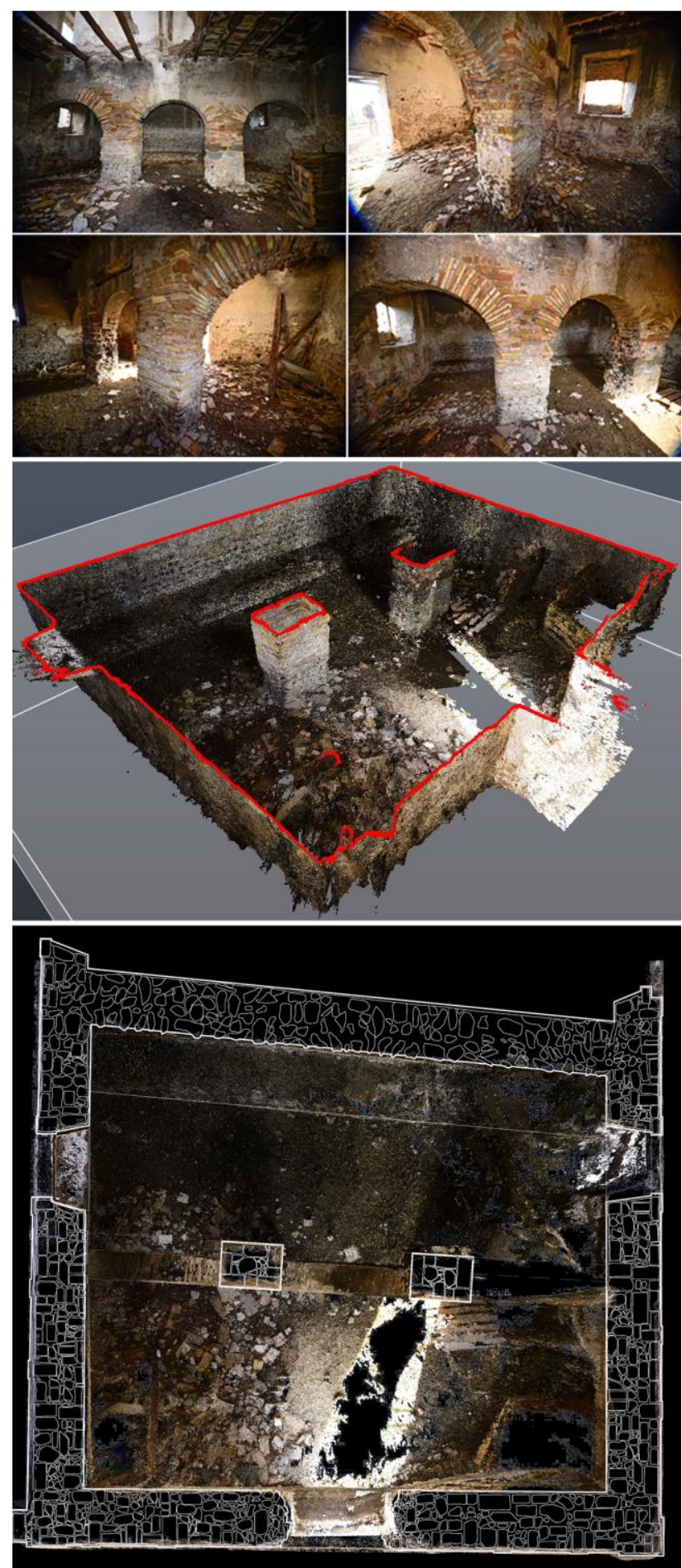

Figure 11. Photomodeling of the sheepfold on the ground floor: two point clouds (external and internal) were connected through the openings. The cloud was used to recreate the geometries of the room.

The collapses in the roof also weighed on the floors between the ground floor and the first floor causing further disruption making the central hall inaccessible. An additional photographic campaign has also allowed to detect the internal environments, which are also deeply degraded and in conditions of abandonment (Figure 11).

\section{CONCLUSIONS}

It would be desirable, as already done with some of the farmhouses (the Casale delle Cavalle Madri at Villa Ada, the Casale la Cervelletta in the Nature Reserve of the Aniene Valley, the Casale degli Strozzi under Monte Mario) a campaign of filing and cataloging the whole heritage that the Roman countryside still hides. This would allow not only to alert the administrations on the state of degradation in which many of the structures concern, but also to activate a programmatic redevelopment of architectures with new uses, compatible with the area plans, and in respect of the potential and consolidated values of the around landscaping and archeology.

\section{ACKNOWLEDGEMENTS}

The survey and photomodeling campaign was carried out thanks to the precious help of Lorenzo De Faveri, Mario Di Chiara and Andrea Zappa.

\section{REFERENCES}

Almagro, A., Et al., 1999. Verso la Carta del Rilievo Architettonico. Testo di base per la definizione dei Temi, in occasione del Seminario Internazionale di Studio "Gli strumenti di conoscenza per il progetto di restauro", Valmontone.

Ashby, T., 1914. La Campagna Romana al tempo di Paolo III, Mappa della Campagna romana del 1547 di Eufrosino della Volpaia riprodotta dall'unico esemplare esistente nella Biblioteca Vaticana, Danesi, Città del Vaticano.

Ashby, T., 1970. The Roman Campagna in the classical times. Ernest Benn Ltd, London, 2nd Revised edition edizion.

Carocci, S., Venditelli, M., 2004. L'origine della Campagna Romana. Casali, Castelli e villaggi nel XII e XIII secolo, Società Romana di Storia Patria, Roma.

Coste, J., 1969. I casali della campagna romana all'inizio del Seicento, in Archivio R. Società Romana di Storia Patria, 92.

Cundari, C., 2015. Il rilievo architettonico. Ragioni, fondamenti, applicazioni. Ermes, Potenza.

De Luca, L., 2011. La fotomodellazione architettonica. Rilievo, modellazione, rappresentazione di edifici a partire da fotografie. Flaccovio Dario, Palermo

Esposito, D., 2005. Architettura e costruzione dei Casali della Campagna romana. Società Romana Storia Patria, Roma.

Feiffer C., 2014. Il progetto di conservazione. Franco Angeli, Milano. ISBN 88-204-3055-X

Geremia, F., Zampilli, M., 2013. Casali della campagna romana esperienze di ricerca per la didattica, Aracne, Roma.

Mazza, A., Tagliaferri, C., 1991. I casali della campagna romana, Pieraldo, Roma.

Parrinello, S., Picchio, F., 2013. Dalla fotografia digitale al modello 3D dell'architettura storica. In DisegnareCon, 6(12), $\mathrm{X} 1-14$. 